\title{
THE PRESCRIBED IMPRISONMENT SENTENCE AS A CONDITION FOR THE CONCLUSION OF THE PLEA AGREEMENT IN THE LEGISLATION OF MONTENEGRO
}

\author{
Dženana M. Nuhodžić1
}

DOI: https://doi.org/10.31410/ERAZ.2019.7

\begin{abstract}
The areas of freedom, security and justice are the norms of primary law and legal acts of secondary law in Europe, which enable the functioning of supranational and national institutions in each particular segment of this field. These norms come from different branches of law, which regulate special relations in the area of freedom, security and justice.

Although there is no explicit division into specific areas according to the Lisbon Treaty, the area of freedom, security and justice represents a unified whole set up in the Title of the TFEU, Article 67 of the TFEU lists some of the basic elements that constitute freedom, security and justice. Within this content section, it is appropriate to make a systematisation and division of the area of freedom, security and justice into several subcategories. This will enable a clear, simpler and more systematic insight into the norms and regulations that constitute the overall legal framework of this area. These are the norms and legislation that are interconnected, conditioned and are in active correlation and interaction with other policies at the continent level. In this context we are also considering the case of plead guilty in the Montenegrin legislation, especially in the part of the prescribed imprisonment sentence as a condition for the conclusion of the Plea Agreement in the legislation of Montenegro.
\end{abstract}

Keywords: Legislation, plea agreement, imprisonment, law, freedom, security.

\section{INTRODUCTORY REMARKS}

$\mathrm{T}$ he Plea Agreement was introduced into the criminal procedure code of Montenegro in 2009.[1] This Code, which came into force on $26^{\text {th }}$ August 2009, the Montenegrin criminal code was enriched by a typical Anglo-American institute. Recognizing the fact that this is a completely new institute, with which the law of Montenegro was not familiar until then, six months after the Code came into force, the provisions of the Agreement started to be applied. Thus, the Plea Agreement has been applied since $26^{\text {th }}$ February 2010.

The legislator estimated that a six-month period would be sufficient for the holders of judicial functions to become acquainted with the new institute in order to successfully apply it in practice. However, it seems that the legislator made a mistake in their assessment. This is supported by the fact that seven months after the beginning of the application of this institute in the proceedings in which the defense attorney, before the main hearings, initiated the conclusion of the Agreement, it was requested the postponement of the main hearings because ,the State Prosecutor has just begun to act on the application of this institute." [2]

The institute of the Plea Agreement is regulated by the Chapter XX of the CPC. Since the adoption of the Code in 2009, until now, the provisions relating to the Plea Agreement have changed, opening even more dilemmas and questions in relation to those that emerged after the initial legal definition of this institute. However, the essence of this institute represents the conclusion

Faculty of Law, Mediterranean University, Josipa Broza bb, Podgorica, Montenegro 
of the Agreement between the two main actors of this procedure, which is the State Prosecutor and the defendant. Namely, by the Agreement the defendant fully acknowledges his/her guilt for one or more acts he/she is charged with, and in return receives certain benefits from the State Prosecutor. These benefits relate to a milder sentence, or other criminal sanctions to be imposed on the defendant. Also, one of the important features of this Agreement is the waiver of the right to appeal by the parties if a judgment is rendered in accordance with the Plea Agreement.

It is important to point out that the final decision on the Agreement is always in the hands of the court. Namely, although the court does not play an active role either in negotiations or in the conclusion of the Agreement, the final decision is always made by the court. The court is the only entity that is authorized to decide on the fate of the Agreement allowing it in that way to produce certain legal effects or become only a dead letter.

\section{THE SCALE OF IMPRISONMENT SENTENCE AS A CONDITION FOR THE CONCLUSION OF THE AGREEMENT - THE ORIGINAL DECISION FROM 2009}

When the Plea Agreement was introduced in 2009 in domestic criminal proceedings, the legislator was fully cautious about it. Since it was not known how the practice would adopt this completely new procedural institute as there was no previous experience with it, its initial application was limited to criminal offences for which an imprisonment sentence of up to ten years was prescribed. Namely, in Article 300 of the current Code, it was prescribed that ,in the case of criminal proceedings for a criminal offence or concurrence of criminal offences for which an imprisonment sentence of up to 10 years is envisaged, the State Prosecutor or the accused person and his/her defense attorney may propose that an Agreement on the admission of guilt could be concluded, i.e. the parties and the defense attorney may propose to the State Prosecutor the conclusion of such an Agreement."

The Plea Agreement, pursuant to the 2009 provisions, could be concluded for a criminal offence for which an imprisonment sentence of up to ten years is envisaged, as well as for concurrence of criminal offences, provided that all such offences were committed in category of offences for which an imprisonment sentence of up to ten years is envisaged.[3] However, this provision was not the most precise one for one reason. As is evident, the number of offences that may have been the subject of the Plea Agreement is not limited. It is therefore not difficult to imagine the following situation in practice. For example, let's take into account the concurrence of criminal offences, which consist of three crimes with imprisonment sentences of up to seven, eight and nine years. With the principle of aspiration, a single sentence in this case could be prescribed between seven years and one month, up to 20 years, which is the overall maximum. Is the conclusion of the Agreement in line with this provision then, if we have in mind that a condition for concluding the Agreement is a prescribed sentence of not more than ten years? We believe that in the above example, there would be no legal restrictions on the conclusion of the Agreement.

The original ban on the conclusion of the Agreement for criminal offences for which an imprisonment sentence of more than ten years is prescribed, is simple to be justified rationally. Namely, it was a completely new institute that in practice had yet to prove its effectiveness. In addition, a large number of criminal offences were found in the permitted zone, thus the Agreement was expected to make a significant contribution to the ending of criminal proceedings at a faster rate. Also, a moderate solution of the legislator should have prevented abuses that this 
institute could possibly brought about. Furthermore, the public opinion was also likely to be taken into account, so the legislator, having understood it, wanted to avoid the possibility of communicating for the most serious crimes.

The relatively mild penal policy in Montenegro, combined with the prescribed restriction, did not represent a suitable ground for reaching some high-profile rates in the application of the Plea Agreement institute. In addition, this should have not been the goal at the very beginning of the application of this new institute. In fact, the moderate caseload burden of courts is a completely satisfactory result. [3] However, as practice showed, in the first years of the application of this institute, the courts were not just relieved in terms of the caseload burden, but this institute had almost never been applied. [4] It is therefore a surprising fact that the legislator, by a later decision of 2015, decided to completely abolish the restriction in the form of a prescribed sentence and allow the conclusion of the Agreement for all crimes (except war crimes and terrorism).

\section{VALID SOLUTION IN THE CRIMINAL PROCEDURE CODE OF MONTENEGRO}

After the initial limitation in the form of the imposed imprisonment sentence, the legislator decided in 2015 to authorize the conclusion of the Agreement for all criminal offences, regardless of the prescribed sentence. Such a decision could be considered a hasty move by the legislator, since the restriction was abolished, and the Agreement was practically not applied in reality. And many European countries abandoned the prescribed restrictions, but they did it more cautiously. Namely, the practice of European countries shows that they spread the circle of criminal offences in relation to which communication is permitted, only after the Agreement in practice had proved successful. [5] Prior to this change it was necessary to carry out a comprehensive and thorough research that would deal with the Plea Agreement in practice.

The legislator's decision to delete the prescribed limit was most likely an attempt by the legislator to „revive” this institute in practice. Since the application of the Plea Agreement in practice had almost never started, the deletion of the prescribed sentence should have increased the application of this institute, which turned out to be right. [6] This again leads us to the issue of penal policy in Montenegro. The reason for the negligible number of concluded agreements is the result of a mild penal policy in Montenegro. Namely, the defendants received low fines in the regular procedure, and therefore they did not have any reason to conclude agreements. One should not ignore the fact that the defendants often tended to delay the criminal proceedings to become obsolete, which was certainly more favorable for them than the conclusion of the Agreement.

Pursuant to the current Criminal Procedure Code, [1] the Plea Agreement can be concluded for all offences prosecuted ex-officio, with the exception of war crimes and terrorist acts. While the prescribed sentence is no longer relevant, the only constraint imposed by the legislator relates to the inability to conclude an Agreement on criminal offences such as war crimes and terrorist acts.

\section{PLEA AGREEMENT AND CRIMINAL OFFENCES OF WAR CRIMES AND TERRORISM}

Why did the legislator choose to ban the conclusion of the Agreement when it comes to war crimes and terrorism? The intent of the legislator, when prescribing this prohibition, is completely understandable. It is clear that these are the crimes that cause inconsiderable and irrepa- 
rable consequences and that the legislator, having in mind this, decided to exclude the application of the Agreement in relation to these crimes. Also, it is clear that the legislator did not want to provide any benefits to perpetrators of these crimes, probably believing that it would not be in line with the principle of justice and that such perpetrators should bear the consequences of their behavior without any convenience. However, it is not clear the criterion of the legislator based on which they narrowed the choice precisely to these criminal offences. Shouldn't the legislator, following the same logic, excluded the application of the Agreement and, for example, a crime against humanity or some other crimes considered as international crimes, or, in general, another serious crime? What were the determining factors that the Plea Agreement was forbidden only in relation to the above crimes? The Criminal Procedure Code prescribes many other crimes that are equally serious and whose consequences are also inconceivable and destructive, so it seems to us that the separation of war crimes and terrorism is not justified.

A more correct solution would be if the legislator allowed the application of the Agreement in relation to all criminal offences, or if they had already decided to exclude the application of the Agreement in relation to the most serious crimes, then it should have been done by imposing the sentence as one of the conditions for the conclusion of the Agreement. Thus, for all criminal offences for which imprisonment is prescribed greater than that set by the legislator as the upper limit, the application of the Agreement would be excluded.

\section{RELATIONSHIP BETWEEN THE PLEA AGREEMENT INSTITUTE AND COOPERATING WITNESSES}

Another dilemma was created by the legislator's decision to exclude the application of the Plea Agreement in relation to the criminal offence of terrorism. If the legislator banned the Agreement for the criminal offence of terrorism because they considered that the perpetrator of this crime should not be given any benefits because of the nature and the weight of this crime, then it should have been consistently followed up by other provisions of the Code. Therefore, when we talk about the criminal offence of terrorism, its relationship with the Plea Agreement Institute, as well as with the Institute of Cooperating Witnesses, is very interesting.

The Institute of Cooperating Witnesses foresees the possibility that a member of an organised criminal group, that is, a criminal organisation against which a criminal complaint is filed or a criminal proceeding for the offence of organised crime (including terrorism) can be heard as a cooperating witness at the proposal of the State Prosecutor (Article 125 CPC). Then, when his/her testimony is of particular relevance for proving the criminal offence and a perpetrator's guilt, or when he/she will help reveal, prove and prevent other crimes and when the significance of his/her testimony to prove the offences and other perpetrators' guilt is more prevalent than the harmful consequences of the crimes he/she is being charged with, a member of an organised criminal group may obtain the status of a cooperating witness. This status implies that a cooperating witness, having given his/her testimony in accordance with the provisions of the CPC about a cooperating witness, cannot be prosecuted for the criminal offence of organised crime that is being conducted.

Here comes the inconsistency of the legislator. How is it possible that the legislator, on the one hand, considers it fair to forbid the perpetrator of the criminal offence of terrorism to conclude the Plea Agreement and, on the other hand, to allow him/her to be completely freed of criminal prosecution for the same offence when he/she receives the status of a cooperating witness. It is 
a completely illogical decision by the legislator that the perpetrator of the criminal offence of terrorism does not have the right to benefits granted by the Agreement, but is given the opportunity to obtain the status of a cooperating witness. This could not be justified by the importance of the witness's testimony, as the testimony that he or she would give in the Plea Agreement could be of the same importance. First, in order to conclude the Agreement, the accused should have fully acknowledged their guilt, which would undoubtedly provide meaningful information. Second, in the course of the negotiations, the prosecutor could conclude the Agreement that „conditions” by the defendant's statement in which he/she would provide all the evidence that would be of significance for proving the criminal offences and other perpetrators guilts.

Therefore, we think that the legislator has not consistently followed the idea that the perpetrators of the criminal offence of terrorism, due to the very nature of the offence, should be denied this opportunity. It even seems to us that in the spirit of justice, it would be possible to conclude a Plea Agreement on the criminal offence of terrorism, rather than the possibility of obtaining the status of a cooperating witness. This, for the reason that, in case of a Plea Agreement, the perpetrator would have to spend some time serving the imprisonment sentence that could not be released on the basis of the Agreement, except that it might have been milder than he/she would receive in the ordinary course of action. By contrast, in relation to a cooperating witness, even when it comes to the crime of terrorism, there will be no grounds to prosecute, which will result in the dismissal of a criminal complaint or the court shall render a decision rejecting the charges. Therefore, we consider that the legislator should be at least consistent in their decision, and when they forbid the possibility of concluding the Plea Agreement for the perpetrators of the criminal offence of terrorism, they should also forbid the possibility of obtaining the status of a cooperating witness when this crime is concerned.

\section{ARGUMENTS FOR THE UNLIMITED APPLICATION OF THE AGREEMENT}

Although we consider that the legislator reacted hastily to the abolition of the ban on concluding the Agreement for crimes for which an imprisonment sentence of more than ten years is envisaged, there are numerous arguments in favour of such a solution. Firstly, how is it possible to justify the decision to allow the law to conclude the Agreement only for certain criminal offences? The possibility of abuse that may have been prevented in this way is not a good reason for doing so, because abuse can also occur when entering into agreements for crimes which impose an imprisonment sentence of up to ten years. And why are the abuses of serious crimes more important than the abuses of those which are less serious?

Secondly, how shall the prosecutor be permitted to negotiate and offer benefits for certain crimes, and for another be denied? This would result in discrimination against prosecutors, depending on their jurisdiction, meaning that for some prosecutors it would be possible to conclude agreements, while others would not have this option. [5] The same argument is on the side of the defendant. While some of them would have the opportunity to negotiate with the prosecutor, others would be excluded. However, we think that this argument should not be of importance, because we consider that the defendants of different crimes should not be treated the same. Namely, the perpetrators of the most serious crimes are more dangerous to society than those who commit less serious crimes; thus, the unequal treatment of the defendants should not be one of the reasons for the unlimited application of the Agreement. 
Nevertheless, a rather strong argument is in favor of the unlimited application of the Plea Agreement Institute. The essence and ratio legis of the introduction of this Institute into legislation is to achieve greater efficiency of criminal proceedings that take too long. Thus, it seems logical that this Agreement is most needed in the case of serious and complex criminal offences for which long/term sentences are prescribed. Solving easier and simpler cases is much more common, which means that the conclusion of agreements in these cases is not of too great significance. [7] Therefore, the question arises as to whether the Plea Agreement can achieve its purpose if its application is limited to offences of law and medium severity? Although there is opinion in the literature [8] that a Plea Agreement should have its application precisely in these crimes, some authors consider that the Agreement should not be limited, that is, they consider that the concept of negotiation should either be unreservedly accepted or completely abandoned. [9]

The strongest argument in favor of the unlimited application of the Plea Agreement must still be found in the legislator's decision that the final settlement decision always belongs to the court. Abuses that could possibly arise can be prevented by the conscientious conduct of the court. The court is solely authorized to decide on the Agreement and only depends on its decision whether the penalties agreed between the parties will be pronounced, or whether the Agreement will produce any legal effect. That is why the conscientious and fair treatment of the court is the only guarantee for the correct application of the Plea Agreement. The court must never be a mere verifier of agreements that prosecutors sign with the defendants, but in each particular case it must be guided by the interests of justice and justice. Therefore, the court must reject the Agreement every time it considers it the right decision, since the effectiveness of the proceedings must not overpower the interest of justice as an imperative of criminal proceedings.

\section{CONCLUDING REMARKS}

The Plea Agreement was introduced into the criminal legislation of Montenegro in 2009. As it was a new procedural institute, the legislator acted rather cautiously during its prescription. Thus, the initial legal solution provided first the ban on the conclusion of the Agreement for criminal offences for which an imprisonment sentence of more than ten years was prescribed. However, in 2015 the legislator decided to abolish this restriction and thus allow the conclusion of the Agreement for all criminal offences, except for war crimes and terrorism. In this paper, we analyzed the arguments pro et contra both legal definitions and pointed out some inconsistencies that can be found in the Criminal Procedure Code on this issue.

\section{REFERENCES}

[1] Criminal Procedure Code, Official Gazette of Montenegro, no. 57/09, 49/10, 47/14, 2/15, $35 / 15,58 / 15,28 / 18$.

[2] Vujanović Svetlana (2012) „Sporazum o priznanju krivice u praksi sudova Crne Gore“, in A. Petrović and I. Jovanović (ed.), Savremene tendencije u krivičnom procesnom zakonodavstvu u zemljama regiona, Belgrade, pp. 120-137.

[3] Škulić Milan (2009), Komentar zakonika o krivičnom postupku, Podgorica.

[4] Report on the application of the Plea Agreement Institute for the period 2010-2015, Ministry of Justice of Montenegro.

[5] Turanjanin Veljko (2016), Agreement on the Admission of Guilt, Doctoral Thesis, University of Kragujevac. 
[6] Reports on the work of the Prosecutorial Council and the State Prosecutor's Office from 2015-2017.

[7] Ikanović Veljko (2013) „Pregovaranje o krivici nakon desetogodišnje primjene u Bosni i Hercegovini“, in I. Jovanović and M. Stanisavljević (ed.), Pojednostavljene forme postupanja u krivičnim stvarima, Belgrade, pp. 179-195.

[8] Bejatović Stanko (2013) „Pojednostavljene forme postupanja kao bitno obeležje reformi krivičnog procesnog zakonodavstva zemalja regiona", in I. Jovanović and M. Stanisavljević (ed.) Pojednostavljene forme postupanja u krivičnim stvarima, Belgrade, pp. 11-31.

[9] Ikanović Veljko (2012) „Materijalnopravni i procesnopravni aspekt priznavanja krivice“, Revija za kriminologiju i krivično pravo, 1-2, pp. 277-291. 